\title{
Nations, Overlapping Generations and Historic Injustice
}

\author{
American Philosophical Quarterly 43, 4 (2006), 357-67
}

\section{Daniel Butt, Oriel College, Oxford}

This article is designed to address a number of related issues concerning the obligations which present day nations and nationals owe, or are owed, as a result of acts of historic injustice committed by, or inflicted upon, their ancestors. The key issue is that of national identity. There is an obvious sense in which it might be said that present day individuals are connected to historic acts of injustice, on account of the fact that they are members of the nations which were originally associated with the acts in question. Nations are historically continuous bodies. This idea is common to any plausible definition of nationhood: thus, for example, David Miller claims that a definitional feature of nationality, "...is that it is an identity that embodies historical continuity", ${ }^{1}$ while Yael Tamir argues that a nation "... may be defined as a community whose members share ...beliefs in a common ancestry and a continuous genealogy." ${ }^{2}$ As such, the existence of nations can and does stretch over many different generations. But what follows from the fact that one can share a national identity with persons who were the perpetrators or victims of past injustice? Is this a morally irrelevant fact, akin to the observation that one can share an eye colour with people who were the perpetrators or victims of past injustice, or is there some sense in which historic acts can affect modern day responsibilities and entitlements? The question has proved problematic within the context of liberal political philosophy because of the discipline's commitment to methodological 
individualism, which suggests that individuals can only be held responsible for their own actions (or inactions), and not those of their predecessors. Within a communitarian context, such thoughts need not be so troublesome. Thus Alastair MacIntyre can argue that obligations of reparation for historic wrongs exist simply as a result of one's community membership:

...the story of my life is always imbedded in the story of those communities from which I derive my identity. I am born with a past; and to try to cut myself off from that past, in the individualist mode, is to deform my present relationships. The possession of an historical identity and the possession of a social identity coincide.

So that:

What I am is in key part what I inherit, a specific past that is present to some degree in my present. I find myself part of a history and that is generally to say, whether I like it or not, whether I recognize it or not, one of the bearers of a tradition. ${ }^{3}$

Most liberal theorists have sought to avoid such definitional solutions, which assign responsibility for injustice without regard to the choices and interests of the individuals involved. As James Fishkin writes, "It hardly seems appropriate to hold people responsible for acts committed by their ancestors." As such, the idea that modern day individuals bear duties of compensation and/or of apology as a result of historic actions is highly controversial, and has led several theorists to devise ingenious solutions, which link present day individuals with the actions of their predecessors by, for example, the 
respect and affection descendants show to their ancestors, ${ }^{5}$ or active association with the actions of these ancestors, ${ }^{6}$ or by assessing the degree to which descendants benefit from the actions of their ancestors, ${ }^{7}$ or by recasting historical injustice as a failure to create appropriate transgenerational commitments to other societies. ${ }^{8}$ The same issues of identity lie at the heart of claims that modern day individuals can be entitled to compensation as a result of actions perpetrated against their ancestors. Janna Thompson refers in this context to "the Exclusion Principle", that "individuals or collectives are entitled to reparation only if they were the ones to whom the injustice was done." 9 Such observations make compensation for historic wrongs difficult if one considers the fact that it seems likely that, were it not for historic injustice, many individuals currently alive would not actually exist. How can it make sense to say that they were harmed by the very actions which caused them to come into existence?

In what follows, a new way of thinking about the relationship of those living in the present with past wrongdoing is put forward. This is done by drawing upon an idea taken from economic theory. The idea in question is that when one thinks of the existence of communities over time, a model of overlapping generations is more realistic than a model of successive generations. The bulk of theoretical consideration of our relation to ancient wrongs has taken place within the context of the latter assumption, which can be broadly described as the idea that one generation replaces another. This in turn leads to the assumption that those living in the present have little or no morally relevant connection to historic injustice: the acts in question were performed by previous generations, not by one's own, current generation. It will be suggested that this way of thinking about past wrongdoing does not take sufficient account of the important idea that the ongoing failure 
to fulfill restitutive and compensatory obligations itself constitutes an ongoing act of injustice. As such, it may well be that those living in the present day are not only connected to past wrongdoing in such a way that gives rise to restitutive and/or compensatory obligations. It may be that they are implicated in wrongdoing, in that they are themselves guilty of injustice to present generations. The article will first consider three relatively uncontroversial propositions, and draw attention to how they fit together. These relate to:
i) the nature of rectificatory duties;
ii) nations and collective responsibility; and
iii) nations and overlapping generations.

\section{THE NATURE OF RECTIFICATORY DUTIES}

The commission of injustice gives rise to duties of rectification, which typically (although not necessarily exclusively) fall upon the wrongdoer. The wrongdoer bears a moral obligation to seek to undo the effects of her actions. This involves seeking to repair the harm which her action has caused to the victim, which may require either seeking to reverse the act (as in the case of the restitution of stolen property, for example) and/or paying compensation, in an effort to provide counterbalancing losses to make up for the harm. She also faces a moral obligation to apologise for her actions. If these duties are not fulfilled, the injustice of her actions continues and is not remitted. Waldron considers the example of the theft of my car. The theft itself is, of course, unjust. But, he notes, "the matter does not end there": 
For now there is a continuing injustice: I lack possession of an automobile to which I am entitled, and the thief possesses an automobile to which she is not entitled. Taking the car away from the thief and returning it to me, the rightful owner, is not a way of compensating me for an injustice that took place in the past; it is a way of remitting an injustice that is ongoing into the present.

Phrases like 'Let bygones be bygones' are inappropriate here. The loss of my car is not a bygone: it is a continuing state of affairs. ${ }^{10}$

This is right as far as it goes, but it can be taken further. What Waldron does not specify is the ongoing agency of the misappropriator. It is not only that Waldron lacks an automobile to which he is entitled, and that the thief possesses an automobile to which she is not entitled. It is also the case that the thief knows this, knows that it is in her power to rectify (or at least seek to repair) the situation, but does nothing. Consider the following example: imagine that, following the theft, the thief had driven home to her house, and gone to sleep. In the course of the night, she is struck by amnesia. The next morning, she has no memory of the act of theft, but finding the car outside her house and the car keys in her possession, she assumes that it belongs to her. This is the same as the situation Waldron describes - a continuing injustice as a result of the unrectified distribution of resources following an unjust act of appropriation. The situation where amnesia does not occur is also a continuing injustice, but in a more profound sense. It is not simply the case that there is what might be called (following James W. Nickel's terminology) a "distortion" within the scheme of distribution;" in addition, the agent responsible for causing the distortion chooses to perpetuate it. In doing so, she acts wrongly. As the result of her actions in misappropriating the car, she has acquired 
restitutive and compensatory obligations. If she fails to fulfill these obligations, she commits a further act of injustice.

Thus, the point that needs to be underlined in this section is the observation that the failure to fulfill compensatory or restitutive obligations constitutes an act of injustice. This is in many ways a self-evident point: if one has moral obligations that one does not meet (in the absence of a morally compelling reason for why one cannot or should not meet them) then one acts wrongly. This is the case regardless of whether the agent who bears the duties has acquired them through her own actions. Consider the following example in relation to the restitution of misappropriated property. Suppose that 200 years ago the rulers of Nation A misappropriated X, an item of property that belonged collectively to the people of Nation B. The rulers of Nation A hid it in a secret location within A's territory. As time passed, the knowledge of the hiding place of X was lost. Now suppose that, earlier this year, $\mathrm{X}$ was discovered by a member of Nation $\mathrm{A}$, and, in accordance with A's laws, was handed over to A's government. If one accepts that X properly belongs to the current members of Nation $\mathrm{B},{ }^{12}$ then it seems that $\mathrm{X}$ must be returned to them. But what if the government of Nation A refuses to do this? It is clear that in this instance a fresh act of injustice is committed. There are now two incidents of injustice to consider. The first was committed two hundred years ago, and those responsible for it are no longer with us. To suggest that any present day individuals were morally responsible for the commission of this act seems wrong. But the second act of injustice is different. It has just been performed by current day individuals. As such, the government of Nation A now owes an apology to Nation B, and may owe further compensation. Now that they are guilty of an act of injustice, the government of Nation A 
is responsible for harm that Nation B suffers as a result of its actions. For example, suppose that $\mathrm{X}$ is a wonderful work of art. If $\mathrm{X}$ was in Nation B's possession it would be able to exhibit it in its national museum, with beneficial consequences in terms of international tourism. The government of Nation A is now responsible for these losses, in a way that it was not prior to the rediscovery of $\mathrm{X}$.

So, the first part of the argument holds that although restitutive and compensatory obligations can be acquired in the absence of moral responsibility for an act of injustice, these obligations are nonetheless moral obligations that compel their holders to act. If such action is not forthcoming, then the bearers of the obligations are themselves the perpetrators of a fresh injustice against the victims of the original act of injustice.

\section{NATIONS AND COLLECTIVE RESPONSIBILITY}

The second step of the argument rests upon a claim that is commonplace within this debate; namely, that it can be possible to hold nations collectively responsible for the actions of their political leaders. The claim requires some explanation. First, it is limited in that it only holds that holding nations collectively responsible is theoretically possible. This is because of the wide variety of relations that might obtain between a people of a given nation and their political leaders. For example, one might, following Miller, posit a continuum of national self-determination, with imperial rule by another power at one extreme and a strong form of democracy at the other. ${ }^{13}$ If a given nation is located at a particular point on the continuum, it remains an open question whether the people of the nation should be held collectively responsible for the actions of their leaders. Such 
judgments depend on the degree of one's faith in the efficacy of democratic institutions, on one's beliefs as to how the actions of political leaders in non-democratic societies can be said to be determined by, or reflective of, the wishes and beliefs of the people as a whole, and on the extent to which one believes that the people are capable of replacing their leaders, should they wish to do so. ${ }^{14}$ Nonetheless, it is widely assumed both that it is possible, in some circumstances, to hold nations responsible for the actions of their leaders, and that democratic nations should indeed be held responsible in this way. Thus, for example, Michael Walzer cites J. Glenn Gray's argument that, “The greater the possibility of free action in the communal sphere the greater the degree of guilt for evil deeds done in the name of everyone."15 While allowing for the possibility of nondemocratic national responsibility, Miller nonetheless holds that, “...the more open and democratic a political community is, the more justified we are in holding its members responsible for the decisions they make and the policies they follow." ${ }^{\text {"16 }}$ Ronald Dworkin argues in a similar fashion:

In a genuine democracy, the people govern... communally. They treat their nation as a collective unit of responsibility, which means that they, as citizens, share derivative responsibility for whatever their government, acting officially, does. ${ }^{17}$

More can be said here about the nature of the "responsibility" in question. First, it need not be maintained that each individual citizen of the polity bears moral responsibility for the actions of their leaders. The individuals in question may have vehemently and vigorously opposed the policy in question. As Walzer argues, "Even in a perfect democracy, it cannot be said that every citizen is the author of every state policy, though 
every one of them can rightly be called to account." ${ }^{, 18}$ The claim is about the obligations of the nation as a whole. As members of the nation, individuals do bear moral obligations to do their part in fulfilling the obligations of the nation itself. Clearly the question of the distribution of costs associated with the fulfillment of these duties is a different matter there is no presumption that each individual need pay an equal amount regardless of their original stance on, and contribution to, the policy in question (although it will clearly be difficult in practice to find a sensitive allocative mechanism. $)^{19}$

Secondly, one can follow David Miller in accepting that even democratic nations do not necessarily bear moral responsibility for the actions of their leaders. Miller instead ascribes, in Tony Honoré's words, outcome responsibility to such nations:

When we say that an agent is outcome responsible for the consequences of her action, we are attributing these consequences to her in such a way that, other things being equal, the resulting benefits and burdens should fall to her. If the consequences include harm to others, then outcome responsibility may, depending on the case, entail liability to compensate for that harm. ${ }^{20}$

In broad terms, it seems that people are happy to say that democratic nations are outcome responsible for the actions of their political leaders. ${ }^{21}$ The leaders are the representatives of the nation; they are chosen by the nation and act on the nation's behalf. There might be some reluctance in accepting the further view that a democratic nation is necessarily morally responsible for the actions of its leaders simply because leaders might act in a way, on a given issue, that does not reflect the will of the nation. The nation has extended a license to its leaders to act on its behalf, and must consequently bear the costs of its 
agents' actions, but this is not the same as saying it bears moral responsibility for these actions. So it might be suggested that the range of cases where the nation is both morally and outcome responsible is a sub-set of the cases where it is outcome responsible. In the real world, the degree of actual control the members of a nation can exercise over its representatives is inevitably somewhat limited.

This said, one would also surely want to allow the possibility of cases where leaders $d o$ act in accordance with the wishes of the nation, so that the nation is morally responsible. Differentiating these cases may well be difficult in practice, although it is also likely that obvious cases of both possibilities will be found. But, in broad terms, one-off actions might be separated from ongoing policies. It might be thought that it is plausible to ascribe moral responsibility to a nation for a policy that is kept in place over a prolonged period of time, as it is harder to describe such a policy as the result of wayward action by political leaders. This does not, of course, mean that one should think of one-off policies as necessarily unreflective of the nation's wishes; this may or may not be the case. Furthermore, one might think that even if a given policy is not the result, directly or indirectly, of the will of the nation, it is still the case that the nation is guilty of collective wrongdoing. One might feel that the nation has been culpable in its selection of leaders. If James hires a posse of notoriously violent Hell's Angels to act as the bouncers at his birthday party, then he acts wrongly, and is blameworthy. If the Hell's Angels subsequently vanish without trace, having roughed up several of his guests, one might believe that his obligations go further than fulfilling the requirements of outcome responsibility. His actions were immorally negligent, and as such he possesses duties not only of compensation but of apology for his own actions. Whether he is actually morally 
responsible for any injuries suffered by his guests can be left as an open question (undeniably, the Hell's Angels in question are themselves morally responsible). ${ }^{22}$ As Steven Sverdlik argues, "We regard people who negligently cause harm as less blameworthy than those who, say, intentionally cause it, but we do regard them as somewhat blameworthy". ${ }^{23}$ So a judgment that A has not directly authorized her agent to commit $\mathrm{X}$ does not mean that she is off the hook altogether in terms of moral responsibility for wrongdoing in connection with $\mathrm{X}$. But regardless, the key point here is that an attribution of outcome, rather than moral, responsibility is sufficient to give rise to rectificatory duties. The question of whether the nation is collectively morally or outcome responsible is not irrelevant: it is likely to make a significant difference to the nature of the apology which is appropriate ${ }^{24}$ But the nation is likely to possess rectificatory duties in either case.

The argument of the two preceding sections can now be brought together. The decision not to fulfill one's compensatory or restitutive duties constitutes an act of injustice. Insofar as it is nations who are failing to fulfill their duties, it is believed that it is possible to hold the nation as a whole collectively responsible for this act of injustice, and in the case of democratic nations, it is generally held that this should be done. ${ }^{25}$

\section{NATIONS AND OVERLAPPING GENERATIONS}

It is at this point that the idea of overlapping generations should be introduced. The conventional view of historic injustice sees its commission as the moral responsibility of previous generations. The question normally asked is whether present generations, who 
are innocent of injustice, nonetheless have obligations to the victims of injustice. But this is not necessarily the most helpful way to consider the matter. Consider again the question of the moral obligations of Nation A, which is refusing to return $\mathrm{X}$ to Nation $\mathrm{B}$. Suppose that the discovery of $\mathrm{X}$, and the refusal to return it, happened at time T. It is now T1: one year after T. What moral obligations does Nation A have to Nation B? Evidently, its restitutive obligation concerning $\mathrm{X}$ remains: it should return it to B. But now compensatory duties have entered the picture. Nation A was responsible for an act of injustice against Nation B at T. So it should not only return X but apologise for the fact that it was not returned at $\mathrm{T}$, and compensate $\mathrm{B}$ for any harm $\mathrm{B}$ has suffered as a result.

This claim evidently rests upon the assumption that the Nation A in question is the same Nation A which was responsible for the action at T. But this might not be strictly accurate. The set of individuals comprising Nation A at T1 is not exactly the same as at T. Some individuals who were alive at $\mathrm{T}$ have died in the intervening year. Other new individuals have joined the nation. For ease of argument, let us assume that these are 18 year olds, whom are deemed to be socially responsible adults within A with, for example, the right to vote. Is it open to Nation A to maintain that it does not bear moral responsibility for its actions at $\mathrm{T}$, as it is not the same entity? Such an argument might be plausible if the composition of Nation A was radically different. Imagine that a peculiar plague (which might be calledl duodevigintitis) had befallen Nation A 6 months ago, killing every individual over the age of 18 . Nation A is now constituted solely by those adults who turned 18 in the intervening six months. In such a case it might be supposed that it is unfair to hold the actions of the preceding generation against them. But, manifestly, this is not how generations work in the real world. Generations do not in fact 
succeed one another, they overlap. The composition of a nation is constantly changing, with individuals being born (or reaching their majority) and dying every hour. So A is not composed of literally the same individuals at $\mathrm{T} 1$ as at $\mathrm{T}$, but it does have (for the sake of argument) $95 \%$ of the same people. In this way, the nation is what Peter French has called a "conglomerate collectivity":

A conglomerate collectivity is an organization of individuals such that its identity is not exhausted by the conjunction of the identities of the parties in the organization. The existence of a conglomerate is compatible with a varying membership. A change in the specific persons associated in a conglomerate does not entail a corresponding change in the identity of the conglomerate. ${ }^{26}$

As a conglomerate collectivity, the obligations Nation A possesses, collectively as a result of its actions at $\mathrm{T}$ remain. So at $\mathrm{T} 1 \mathrm{Nation} \mathrm{A}$ has moral obligations to Nation $\mathrm{B}$ as a result of Nation A's previous actions at T. For $95 \%$ of the population this seems straightforward: they acquired the obligations as a result of their actions at $\mathrm{T}$, and these obligations remain. But what of the new 5\%? It cannot be said that they are morally responsible for the wrongdoing at $\mathrm{T}$, any more than the remaining $95 \%$ were responsible for the original misappropriation of X. But they are now members of a collective which does bear obligations to $\mathrm{B}$, as a result of the obligations of an overwhelming majority of their fellow members. If, at T1, A once again refuses to return X, they are implicated in the wrongdoing as members of the collective, just as the other $95 \%$ were at $\mathrm{T}$. But A has compensatory duties as well as restitutive obligations at $\mathrm{T} 1$, as a result of the decision not to return $\mathrm{X}$ at T. So, in a sense, two acts of injustice are perpetrated at T1. First, $\mathrm{X}$ is not 
returned, and secondly, compensation is not paid for the immoral retention of X. This can clearly be seen if one imagines that a decision is taken at $\mathrm{T} 1$ to return $\mathrm{X}$ but not to compensate B for its retention over the past 12 months. This would still constitute a new, albeit single, act of injustice. And just as the original 95\% were implicated in this decision at $\mathrm{T}$, so all $100 \%$ of the population are implicated at $\mathrm{T} 1$. If nations can be held responsible for democratic outcomes, then Nation A is collectively responsible for wrongdoing at $\mathrm{T} 1$.

Fairly obviously, this process can be run over and over again. Consider a simplified version of the example. Imagine that, at T, a referendum is held in A. $100 \%$ of the population votes against the return of $\mathrm{X}$. As a result, the assignation of moral responsibility is straightforward. The nation as a whole is collectively responsible for the decision. Each individual is also, individually, morally responsible for their own actions. Both the nation, and each individual within the nation, has acted wrongly. The members of Nation A are nonetheless conscious of the demands being made by the members of Nation B, and so decide to hold a referendum on the subject of X every year. By T1, things have changed somewhat. A majority of Nation A resolves to return X to B, and this duly happens. But the issue of the yearlong wrongful retention of $\mathrm{X}$ is not so happily resolved. In fact, at T1 $100 \%$ of the population vote against paying Nation B compensation for the retention of $X$. In so doing, they all act wrongly, even the $5 \%$ of the population who were not responsible for the decision at $\mathrm{T}$. The question the new $5 \%$ have faced is not that of whether they are morally responsible for the actions at T; it is whether the nation as a collective is responsible. Had the composition of the nation changed entirely between $\mathrm{T}$ and $\mathrm{T} 1$, the answer to this question would be no. But given that the 
membership of the vast majority of the nation is the same at both $\mathrm{T}$ and $\mathrm{T} 1$, the collective responsibility remains. The result is that a new incidence of injustice is committed. Again, Nation A is collectively responsible for the outcome, and every member of Nation A is also individually to blame for acting wrongly. If the pattern is repeated every successive year, it follows that a new act of injustice is committed every year. So at T50, 51 separate acts of injustice have been committed by Nation A against Nation B. Even if the population of $\mathrm{A}$ is completely different at $\mathrm{T} 50$ than at $\mathrm{T}$ or at $\mathrm{T} 1$, in that not a single member of A at T1 is still alive, every member of Nation A has acted wrongly in relation to Nation B. As such, they are perpetrators of injustice in relation to B. They owe Nation B an apology and may owe them compensation for harm suffered.

The conclusion on compensation is conditional, while that on apologising is not, because B is only entitled to compensation insofar as it has suffered as an automatic result of the acts of injustice which A has committed. Of course, it may be that after fifty years there is no longer a perceptible harm which has resulted from A's actions. If the people of B gradually lose awareness of and interest in the situation, it will cease to be significant from a moral viewpoint. But this need not necessarily be so. In the case of major incidents of international wrongdoing, which, for example, upset the balance of international trade, or severely damage a nation's political or economic infrastructure, the automatic effects of injustice may be extremely long-lasting. It is also possible that A's actions will continue to rankle with the people of B, who resent A's continual unwillingness to fulfill its obligations ${ }^{27} \mathrm{~A}$ key point here is that the harm to $\mathrm{B}$ is not assessed simply by looking at the effects on B of the original act of injustice, that is, the harm suffered between $\mathrm{T}$ and $\mathrm{T} 1$. When looking at the present population of $\mathrm{B}$, it is 
necessary to assess the extent to which members of B have been harmed by each incidence of injustice which has occurred within their own lifetime. So the question is not simply whether the present members of Nation B have been harmed by the original nonreturn of X. The question is whether they have been harmed by Nation A's refusal not to compensate Nation B for the non-return of X, or by Nation A's refusal to compensate Nation B for their earlier refusal to compensate Nation B for the non-return of X, and so on. In some cases, the harm caused may dwindle with the passing of time and become negligible or non-existent. But this need not happen.

The situation with apology is more straightforward. For as long as an apology is not forthcoming, an apology is owed. The precise nature of the apology will inevitably change over time. As the generations overlap, it will not be the case that Nation A will be apologising for action Y per se. Rather, they will be apologising for not apologising for Y, or apologising for not apologising for not apologising for $\mathrm{Y}$, and so on. As with compensation, it is possible for the question of the apology to become unimportant. But, unlike compensation, it is not possible for it actually to disappear. The nature of the obligation to apologise for wrongdoing means that the obligation exists even in the absence of harm to the victim.

It should be clear that the above example is simplified in two important aspects. First, $100 \%$ of the population are opposed to a just resolution of the situation. Secondly, these individuals take a conscious and deliberate decision to act unjustly. But neither simplification, if relaxed, affects the substantive argument. In the first instance, let us suppose that the decision not to compensate Nation B is more controversial than the 
above example suggests. Perhaps, in the referendum, $40 \%$ of the population supports a just resolution while $60 \%$ opposes it. The outcome is nonetheless unjust, and, as members of Nation A, the $40 \%$ who voted justly are nonetheless implicated in the decision. To be sure, their level of implication is not the same as the other $60 \%$. They are not themselves morally at fault. But it is still the case that their nation has acted unjustly. As such, as moral agents, they have a moral duty to support moves in favour of the reversal of the decision. The nation has collectively acted wrongly, despite their best efforts, and so they should vote in favour of a just resolution at the next referendum.

The second simplification concerns the fiction of yearly referenda on a nation's restitutive obligations. The issue of the annual nature of these referenda is, obviously, merely a way of conceptualising the ongoing nature of a nation's refusal to meet its restitutive obligations. Nations do not face the question of whether to meet their obligations every year; they face them constantly, in that an ongoing refusal to so do represents a continuous act of injustice. It is true that these obligations are not normally explicitly put to a single public vote, far less to a regular series of such votes. But if one is willing to hold a people responsible for the actions and inactions of their governments then there is no reason why one should not be prepared to state that they act unjustly insofar as they fail to fulfill their ongoing collective responsibilities to others. ${ }^{28}$

Finally, a focus on the concept of overlapping generations also allows us a ready response to those who follow Derek Parfit in arguing that present day individuals cannot be deemed to have been harmed by historic events which caused the said individuals to 
come into existence. Such a claim is extremely common in the literature. Thus, Jeremy Waldron, in discussing the counterfactual approach to the rectification of injustice, notes:

...the events of justice and injustice may make a considerable difference in who exists at a later

time. Children may be born and leave descendants, who would not have existed if the injustice had not occurred. Short of putting them to death for their repugnancy to our counterfactuals, the present approach offers no guidance at all as to how their claims are to be dealt with. ${ }^{29}$

Samuel C. Wheeler III is more forthright:

I take it as a premise that an individual is entitled to reparations for an unjust event only if the individual would still exist if the unjust event had not happened. ${ }^{30}$

If one considers these individuals as members of a nation within the context of the continuing non-rectification of injustice, the problem disappears. Consider the following example. At time T, Nation C wrongs Nation D by committing action Y. At T0.1, 36.5 days after T, M is conceived. Y had a major effect on M's parents - it is unlikely that they would even have met had Y not occurred, and wildly unlikely that the precise individual $\mathrm{M}$ would have been conceived. So one may, broadly speaking, say that not only has M benefited from $\mathrm{Y}$, but that $\mathrm{M}$ owes her existence to $\mathrm{Y}$. This is often, within the literature on the subject, taken as sufficient to nullify, or at least to call into question, M's claim to compensation for $\mathrm{Y}$, on the basis that $\mathrm{M}$ has not been harmed by $\mathrm{Y}$.

However, once it is understood that it is not simply $\mathrm{Y}$ for which compensation is being paid, this objection ceases to have force. Again using a year as the basic unit, one can 
imagine that at T1, T2 and so forth Nation D is harmed by Nation C's ongoing unwillingness to pay compensation. Once more, it should be stressed that this is not just an unwillingness to pay compensation for Y. It is also an unwillingness to pay compensation for not paying compensation at $\mathrm{T} 1$, at $\mathrm{T} 2$ and so on. As a member of Nation D, M is harmed by each of these subsequent acts of injustice. ${ }^{31}$ Take, for example, year T20. M is now an adult member of Nation D. Nation D is still owed compensation, and an apology, for Y (leaving to one side the subsequent injustices at T1, T2 etc.). A majority of the members of Nation D were alive, and full members of Nation $\mathrm{D}$, at T. As a member of Nation D, M is also owed compensation and an apology. When this is not forthcoming at T20, she is harmed, and wronged. Thus, it is not justifiable for the members of Nation $\mathrm{C}$ to resist demands that they pay compensation by arguing at, let us say, T50 that the majority of members of Nation D were not alive at the time of Y, and in fact owe their existence to Y. This may well be true. But the basis on which members of $\mathrm{D}$ are claiming compensation at T50 is not the harm they have suffered at T. Instead, they are claiming compensation for harm caused to them by Nation C's ongoing refusal to compensate their nation in the intervening years after $\mathrm{T}$ and up to T50. Because each refusal by $\mathrm{C}$ to compensate $\mathrm{D}$ constitutes a separate act of injustice, the question of M's relation to $\mathrm{Y}$ is beside the point. $\mathrm{M}$ does not owe her existence to the acts of injustice at T1, T2 T3 or T4. Each of these constitutes a separate act of injustice and, as such, leaves C open to morally valid compensation claims. Historic injustice casts a long shadow. ${ }^{32}$

\footnotetext{
${ }^{1}$ David Miller, On Nationality (Oxford: Clarendon, 1995), p. 23.

${ }^{2}$ Yael Tamir, “The Enigma of Nationalism”, World Politics 47 (1995), 418-40 at p. 425.

${ }^{3}$ Alastair MacIntyre, After Virtue: A Study in Moral Theory (London: Duckworth, 1987), p. 221.
} 
${ }^{4}$ James S. Fishkin, "Justice Between Generations" in John W. Chapman (ed.), Nomos XXXIII:

Compensatory Justice (New York, New York University Press, 1991), pp. 85-96.

${ }^{5}$ Samuel C. Wheeler, "Reparations Reconstructed", American Philosophical Quarterly 34 (1997), 301-318.

${ }^{6}$ Farid Abdel-Nour, "National Responsibility”, Political Theory 31 (2003), 693-719.

${ }^{7}$ Daniel Butt, “On Benefiting from Injustice”, Canadian Journal of Philosophy (forthcoming).

${ }^{8}$ Janna Thompson, Taking Responsibility for the Past (Cambridge: Polity, 2002).

9 Janna Thompson, "Historical Injustice and Reparation: Justifying Claims of Descendants", Ethics 112 (2001), 114-35 at p. 116.

${ }^{10}$ Jeremy Waldron, "Superseding Historic Injustice”, Ethics 103 (1992), 4-28 at p. 14.

${ }^{11}$ James W. Nickel, “Justice in Compensation”, William and Mary Law Review 18 (1976), 379-88 at p. 382 .

${ }^{12}$ Evidently, such a claim would need to be justified by reference to an appropriate argument concerning the justifiability of inheritance.

${ }^{13}$ David Miller, "Holding Nations Responsible", Ethics 114 (2004), 240-68 at p. 259.

${ }^{14}$ This issue is discussed at length by Miller in "Holding Nations Responsible", pp. 260-2.

${ }^{15}$ Cited in Michael Walzer, Just and Unjust Wars (New York: Basic Books, 1977), p. 298. As

Walzer notes, the term "guilt" is controversial here, but if replaced by "responsibility" it seems less problematic.

${ }^{16}$ Miller, "Holding Nations Responsible", p. 262.

${ }^{17}$ Ronald Dworkin, "Equality, Democracy and Constitution: We the People in Court", Alberta Law Review 28 (1990), 324-46 at p. 337.

${ }^{18}$ Walzer, Just and Unjust Wars, p. 299.

${ }^{19}$ See Erin Kelly, “The Burdens of Collective Liability”, in Dean K. Chatterjee and Dan E. Scheid (eds.), Ethics and Foreign Intervention (Cambridge: Cambridge University Press, 2003), pp. 118139.

${ }^{20}$ Miller, "Holding Nations Responsible", pp. 244-5. 
${ }^{21}$ For the sake of exposition, it is assumed here that "democratic nations" refers to self-governing nation-states. There are obviously important issues to be addressed in the real world concerning states comprised of more than or less than one nation, but these are left to one side.

${ }^{22}$ Miller describes moral responsibility as being linked conceptually to liability for blame, so that, "to say of A that he is morally responsible for state $\mathrm{S}$ is to say that he has contributed to the bringing about of S in such a way as to incur blame." (David Miller, "Distributing Responsibilities", Journal of Political Philosophy 9 (2001), 453-71 at p.459.) Such a definition explicitly includes in its scope negligent action that leads to harm. The contrary view is put forward by J. L. Mackie, who adopts "the straight rule of responsibility: an agent is responsible for all and only his intentional actions." This means that one should not hold a person responsible for unforeseen consequences of "inadvertent negligence". (Quoted in Peter Cane, "Responsibility and Fault: A Relational and Functional Approach to Responsibility", in Cane and Gardner (eds.), Relating to Responsibility (Oxford: Hart Publishing, 2001), 81-110 at p. 95.

${ }^{23}$ Steven Sverdlik, "Pure Negligence", American Philosophical Quarterly 30 (1993), 137-49 at p. 137.

${ }^{24}$ For relevant discussion on different forms of apology, see Michael Cunningham, "Saying Sorry: the Politics of Apology", The Political Quarterly 70 (1999), 285-93.

${ }^{25}$ Again, the question of the responsibility of undemocratic nations can be left as an open question, the resolution to which depends on one's view on if and how such nations can acquire collective responsibility.

${ }^{26}$ Peter French, Collective and Corporate Responsibility (New York: Columbia University Press, 1984), p. 13.

${ }^{27}$ Of course, this is likely to be the case given the unlikely scenario of specific annual decisions not to fulfill these commitments! But it may still generally be the case that the fact of an ongoing, deliberately unrectified injustice will continue to rankle. From the victim's perspective, it may be the case that an unrectified injustice does not grow less significant but more significant with time. The ongoing refusal to address the issue in such a case simply makes the situation worse. 
${ }^{28}$ May distinguishes between democratic decisions which are the result of collective omission and of collective inaction as follows: "If people are able to decide how to act as a group, and they decide not to act, then their failure to act constitutes a collective omission. If people are able to decide how to act as a group, but they do not reach any decisions, and as a result nothing is done, then this is a clear case of collective inaction." In either case, it seems legitimate to ascribe responsibility to the group. (Larry May, Sharing Responsibility [Chicago: University of Chicago Press, 1992], p. 108.)

${ }^{29}$ Waldron, "Superseding Historic Injustice”, p. 12.

${ }^{30}$ Wheeler, “Reparations Reconstructed”, p. 302

${ }^{31}$ There is an obvious, and deliberate, asymmetry here between the ages at which individuals are deemed to be responsible for the actions of their nation and that at which they are deemed to be harmed by harms to their nation. This simply reflects the degree of agency necessary for responsibility in the former case.

${ }^{32}$ I would like to thank Francesca Galligan, David Miller, Henry Shue and Hillel Steiner for their comments on this article, as well as the members of the Nuffield College Workshop in Political Theory in Oxford. 